\title{
Communication
}

[Comunicação]

\section{Monitoring of Leptospira in captive turtles by DNA analysis}

[Monitoramento de Leptospira em quelônios mantidos em cativeiro pela análise de DNA]

\author{
G.S.S. Mesquita ${ }^{1}$, K.S. Rocha ${ }^{1}$, M.R. Albuquerque ${ }^{1}$, J. Silva ${ }^{1}$, M.E.T. Gomes ${ }^{2}$, \\ T.R.M. Monteiro ${ }^{3}$, C.C.G. Moraes ${ }^{1} *$
}

\author{
${ }^{1}$ Programa de pós-graduação - Instituto de Medicina Veterinária - Universidade Federal do Pará - Castanhal, PA \\ ${ }^{2}$ Aluno de graduação - Faculdade de Medicina Veterinária - Instituto de Medicina Veterinária - Universidade \\ Federal do Pará - Castanhal, PA \\ ${ }^{3}$ Residência Multiprofissional - Instituto de Saúde e Produção Animal - Universidade Federal \\ Rural da Amazônia - Belém, PA
}

\begin{abstract}
Zoological and botanical parks play a fundamental role in the conservation of biodiversity, and serve as valuable sources of information (Costa, 2004). However, the spread of pathogens among different confined wild species is highly probable due to population densification in smaller facilities (Cubas, 2008). One of the important zoonotic agents is Leptospira spp., a pathogen that can infect different animal species without necessarily causing any clinical symptoms, and that can transform the hosts into potential carriers (Ebani, 2017). Molecular diagnostic techniques can effectively detect this pathogen with high sensitivity and specificity (Cordeiro et al., 2017).
\end{abstract}

Only a few studies on infectious diseases in wild animals have been reported so far; specifically, the data on infectious diseases in reptiles are very limited. Furthermore, there is limited knowledge about the epidemiology of Leptospira spp. infection in these reptiles (Ebani, 2017). Certain aquatic species of turtles may be more exposed to Leptospira spp., as these bacteria are well adapted to aquatic environments and can survive for several months in moist soils and fresh water (Plank and Dean, 2000). Thus, the constant contact between these captive-bred species and caretakers/professional zookeepers may represent a risk of bacterial transmission to the people belonging to this occupational group (Ebani, 2017). The aim of this study was to search for Leptospira spp. in blood samples from chelonians kept in captivity at Bosque Rodrigues Alves (Jardim Botânico da Amazônia) and thus contribute new reports.

The aquatic turtles in the present study resided in artificial lagoons inside the Bosque, where the water was not managed regularly. A total of 148 turtles belonging to six different species were included in the study; these consisted of 98 males, 38 females, and 12 individuals of undefined sex due to their very young age, weighing $540 \mathrm{~g}$ to $21.92 \mathrm{~kg}$, with no clinical signs of infection (Table 1). The authorization for the collection of biological material for this study was granted by the Biodiversity Authorization and Information System (SISBIO) issued based on Normative Instruction $\mathrm{n}^{\mathrm{o}} 03 / 2014$, with the authentication code: 59238645 .

Blood samples were collected aseptically after physically restraining the animals carefully to minimize stress. Around $1-2 \mathrm{~mL}$ of blood were collected in anticoagulant tubes from the dorsal caudal vein or occipital sinus of the animals using $3 \mathrm{~mL}$ syringes (Figure 1) and stored at $-20^{\circ} \mathrm{C}$ for subsequent analysis.

Recebido em 16 de março de 2020

Aceito em 25 de agosto de 2020

*Autor para correspondência (corresponding author)

E-mail: ccmoraes@ufpa.br 
Table 1. Categorization of turtles included in this study based on the species, common name, and habitat

\begin{tabular}{lccc}
\hline \multicolumn{1}{c}{ Species } & Common name & Habitat & Number of animals \\
\hline Podocnemis expansa & Amazonian-turtle & Aquatic & 10 \\
Podocnemis unicifilis & Tracajá & Aquatic & 95 \\
Podocnemis sextuberculata & Iaçá/Pitiú & Aquatic & 4 \\
Rhinoclemmys punctularia & Perema & Aquatic & 30 \\
Chelonoidis denticulatus & Yellow-jabuti/Jabuti-tinga & Terrestrial & 1 \\
Chelonoidis carbonarius & Red-jabuti/Jabuti-piranga & Terrestrial & 8 \\
\hline Total & & & 148 \\
\hline
\end{tabular}

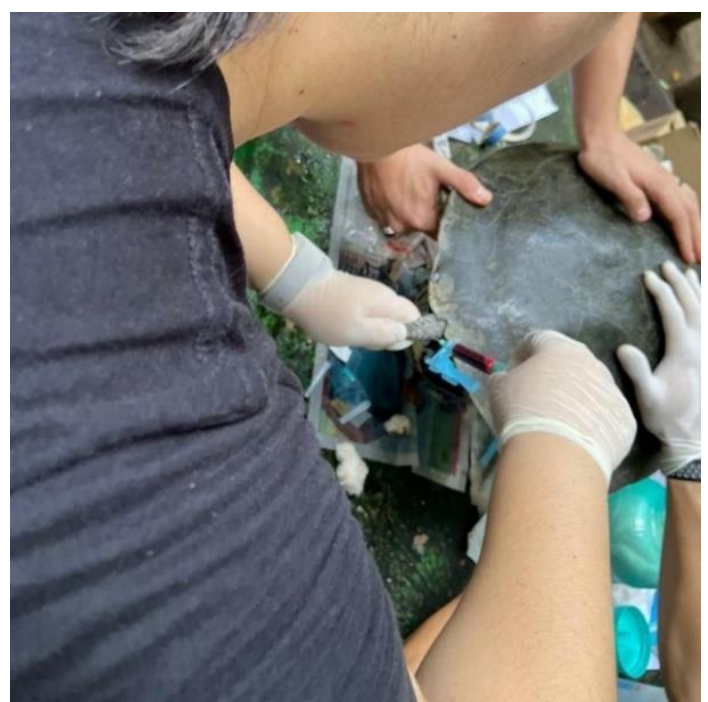

Figure 1. Blood collection from Amazonian-turtles (Podocnemis expansa) through puncture of the dorsal caudal vein. Source: Ellen Yasmin Eguchi Mesquita.

DNA was extracted from the blood samples using the ReliaPrep ${ }^{\mathrm{TM}}$ Blood gDNA Miniprep System (Promega ${ }^{\circledR}$, USA) following the manufacturer's protocol. The sequences of the primers specific to Leptospira spp. DNA, Lep 1 and Lep 2 as reported by Merien et al. (1992), were obtained from GenBank. Further, $5 \mu \mathrm{L}$ of DNA extracted from Leptospira, obtained from culturing Leptospira interrogans serovar Canicola in $\mathrm{EMJH}$, and $5 \mu \mathrm{L}$ of sterile water were used as a positive and negative control, respectively. Polymerase chain reaction (PCR) was performed to detect a $331 \mathrm{bp}$ fragment following the protocol described by Rocha (2016).

The products were run on a $1.5 \%$ agarose gel and stained with Safer dye (Kasvi ${ }^{\circledR}$, Brazil) to visualize the amplified fragments and verify DNA quality and integrity. The samples were visualized under an ultraviolet (UV) transilluminator coupled to a photo documentation system (Gel Doc $^{\mathrm{TM}} \mathrm{XR}+$ Imager, Bio-Rad ${ }^{\circledR}$, USA). Our experiment showed that all the animals included in this study were negative for Leptospira spp. This is the first time a molecular diagnostic technique was used to detect Leptospira spp. in blood samples collected from turtles (Figure 2).

Alves Jr (2013) analyzed urine and stomach content samples from 120 free-living Amazonianturtles (Podocnemis expansa) by PCR using the Lep 1 and Lep 2 primers and detected Leptospira spp. DNA in at least two stomach content samples. The author also analyzed samples from 480 Amazonian-turtles ( $P$. expansa) bred in captivity and detected the bacterial DNA in two urine samples. In contrast to the present study, this author assayed different types of biological samples, which may have aided the detection of the bacteria. Another study by Oliveira (2013) detected Leptospira spp. in 11 samples, including eight stomach wash and three cloacal wash samples, from 66 Geoffroy's side-necked turtles (Phrynops geoffroanus). 


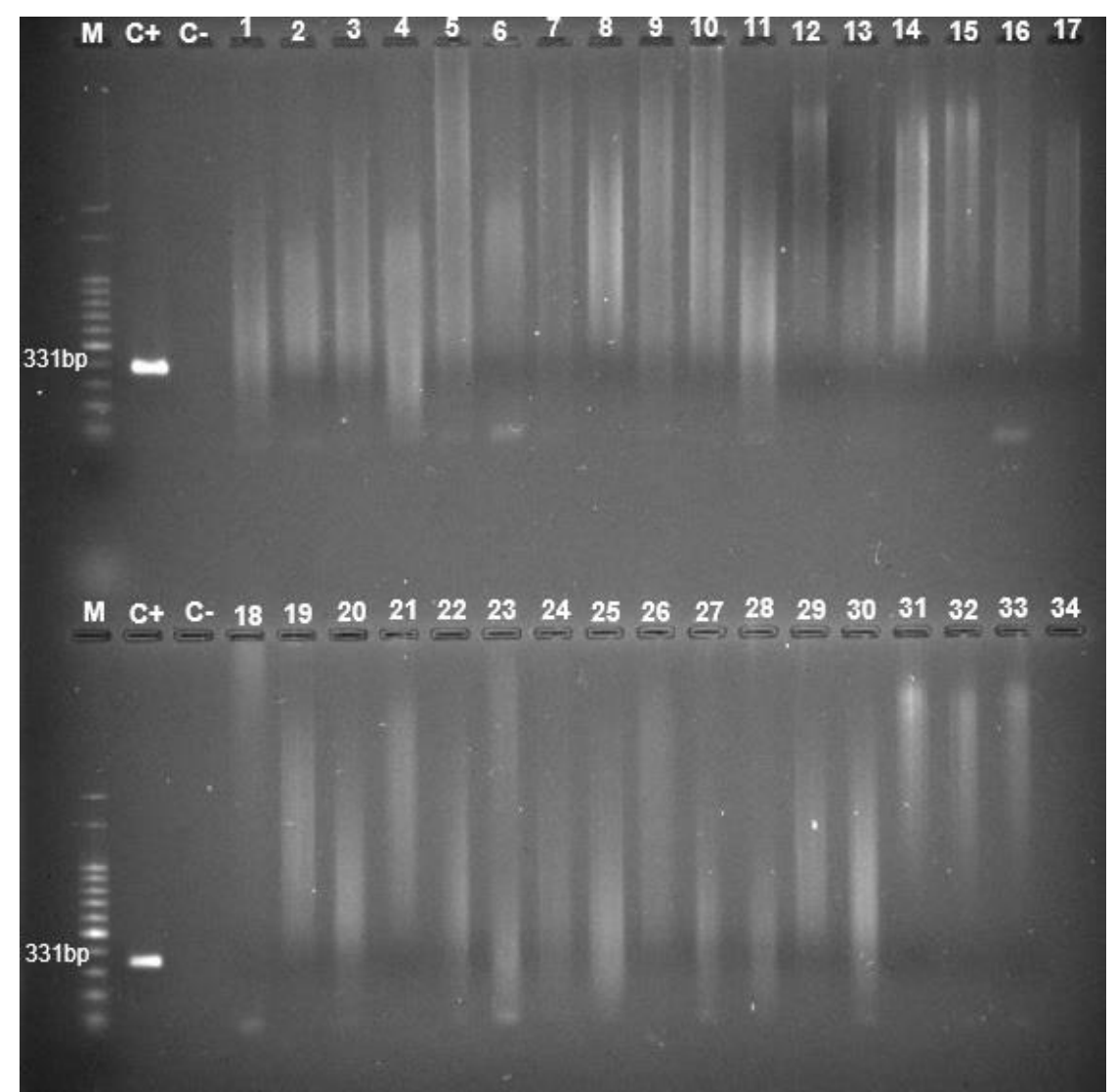

Figure 2. Results of the PCR analysis visualized on 1.5\% agarose gel. (M: molecular weight marker 100 bp; C+: positive control; C-: negative control; 1-34: turtle samples).

That study analyzed free-living animals from a stream located in an urban environment, which may have increased the probability of encountering the pathogen, as such an environment comprises rodents and other animal species that provide favorable conditions for Leptospira spp. to remain alive for long periods (Ebani, 2017). The animals included in the present study lived in artificial lagoons, in which the water was not managed regularly; of note, all samples showed negative results for Leptospira spp. A possible explanation for this result may be because these species coexist in the aquatic environment for many years and, therefore, Testudines may have developed mechanisms to prevent infections by this bacterium, as suggested by Oliveira (2013).

Another possible explanation is that the animals included in this study might have come into contact with the pathogen; however, by the start of the study, these animals might have eliminated the pathogen from their bloodstream or the infection might have already progressed into the chronic phase, therefore rendering pathogen detection in the blood difficult. Further research is necessary to determine whether blood is an ideal biological material for the detection of Leptospira spp. infection in turtles. The results of this research contributed to new reports regarding the possible infection by Leptospira spp. in reptiles kept in captivity.

However, it is important to apply other methodologies, such as serological and physical examination, to determine the health of the animals, and implement control measures to prevent the possible transmission of these zoonotic agents to other animals and to professional caregivers/caretakers, thereby avoiding possible damage to public health.

Keywords: testudines, Leptospira spp., reptiles, Amazon, public health 


\section{RESUMO}

Existem poucos estudos sobre doenças infecciosas em animais silvestres. O objetivo deste estudo foi pesquisar DNA de Leptospira spp. em sangue de tartarugas mantidas em cativeiro, pertencentes ao Bosque Rodrigues Alves (Jardim Zoobotânico da Amazônia). O DNA foi isolado das amostras de sangue coletadas de 148 tartarugas pertencentes a seis espécies diferentes. A reação em cadeia da polimerase (PCR) foi realizada utilizando-se iniciadores específicos para DNA de Leptospira spp. Nenhuma das amostras apresentou resultado positivo para Leptospira spp.

Palavras-chave: testudines, Leptospira spp., répteis, Amazônia, saúde pública

\section{ACKNOWLEDGEMENTS}

The authors would like to thank the employees, interns, and technicians of Bosque Rodrigo Alves for their assistance, and particularly the responsible veterinarian Ellen Yasmin Eguchi Mesquita, for allowing the research, helping to obtain the samples, and providing photos of the sample collection.

\section{REFERENCES}

ALVES JÚNIOR, J.R.F. Leptospira spp. $e$ Brucella spp. em tartarugas-da-amazônia (Podocnemis expansa) do vale do rio Araguaia GO. 2013. 89f. Tese (Doutorado em Medicina Veterinária) - Faculdade de Ciências Agrárias e Veterinárias, Universidade Estadual Paulista, Jaboticabal, SP.

CORDEIRO, C.T.; VIEIRA, R.F.C.; OLIVEIRA, S.T. Anticorpos anti-Leptospira spp. e leptospirúria em gatos na região metropolitana de Curitiba/PR-Brasil. Arch. Vet. Sci., v.22, p.13138, 2017.

COSTA, G.O. Educação ambiental - experiências dos zoológicos brasileiros. Rev. Eletron. Mestrado Educ. Ambient., v.13, p.140-50, 2004.

CUBAS, Z.S. Biossegurança na manipulação de animais silvestres - biossegurança em zoológicos. Ciênc. Vet. Tróp., v.11, p.174-77, 2008.
EBANI, V.V. Domestic reptiles as source of zoonotic bacteria: a mini review. Asian Pac. J. Trop. Med., v.10, p.723-728, 2017.

MERIEN, F.; AMOURIAUX, P.; PEROLAT, P. et al. Polymerase chain reaction for detection of Leptospira spp. in clinical samples. J. Clin. Microbiol., v.9, p.2219-2224, 1992.

OLIVEIRA, J.P. Detecção de Salmonella spp. e Leptospira spp. em Phrynops geoffroanus (Cágado-de-barbicha) em ambiente urbano. 2013. 51f. Dissertação (Mestrado em Medicina Veterinária) - Faculdade de Ciências Agrárias e Veterinárias, Universidade Estadual Paulista, Jaboticabal, SP.

PLANK, R.; DEAN, D. Overview of epidemiology microbiology, and pathogenesis of Leptospira spp. in humans. Microbes Infect., v.2, p.1265-1276, 2000.

ROCHA, K.S. Pesquisa de Leptospira spp. em fragmentos de fígado e rim de marsupiais $e$ roedores de vida livre em fragmento florestal na Amazônia Oriental. 2016. 40f. Dissertação (Mestrado em Medicina Veterinária) - Instituto de Medicina Veterinária, Universidade Federal do Pará, Castanhal, PA. 